\title{
Lewinskya anaglyptodon var. ochyrarum (Orthotrichaceae), a new variety of epiphytic moss from Chile
}

Vítězslav Plášek

Lewinskya anaglyptodon var. ochyrarum (Orthotrichaceae), a new variety of epiphytic moss from Chile. - Acta Mus. Siles. Sci. Natur., 68: 175-178, 2019.

\begin{abstract}
Lewinskya anaglyptodon var. ochyrarum Plášek, var. nova, is a confirmed record of a new variety from Chile. The new taxon is described and illustrated by macro photos and micro photos from SEM. It is characterized by having double peristome with conspicuous endostome segments which are unknown in the type variety.
\end{abstract}

Key words: Lewinskya anaglyptodon, Lewinskya rupestris, mosses, new variety, taxonomy, South America

\section{Introduction}

The genus Lewinskya F.Lara, Garilleti \& Goffinet is a widespread moss group, which comprises 70 taxa (66 species and 4 varieties), which are mostly epiphytes, with some being saxicolous (Lara et al. 2016). Thirty-two taxa (46\% of the total) occur in the Southern Hemisphere. In Chile, 14 taxa of the genus were known until recently (Lewinsky 1987, Müller 2009).

During a bryofloristic survey in the Magallanes Region (Patagonia, Chile) in January 2011 a noteworthy epiphytic moss from the genus Lewinskya was collected. Upon closer examination the specimen proved to represent a variety new to science.

\section{Lewinskya anaglyptodon (Cardot \& Broth.) F.Lara, Garilleti \& Goffinet var. ochyrarum Plášek, var. nova}

TYPE. Chile. XII. Magallanes Region. $43 \mathrm{~km}$ NW of Puerto Natales town, edge of Torres del Paine National

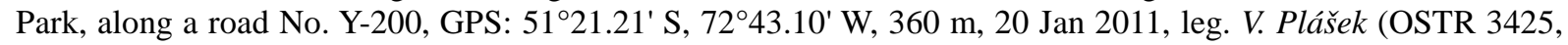
holotype)

Plantae usque ad $2 \mathrm{~cm}$ altae, foliis erecto-adpressis, lanceolatis, apicis acutis. Capsulae immersae vel emergentes, cylindricae vel obloideo-cylindricae. Stomata phaneropora, in parte inferiore capsulae locata. Peristomium duplex; dentes exostomii 16, sicce recurvati, papillosi; endostomium brevius, constans ex 8 segmentis glabris, biseriatis. Calyptra obloideo-conica, in dimidio superiore dense hirsuta.

\section{Description}

Plants green to olive green, up to $20 \mathrm{~mm}$ tall. Stem sparsely branched, branches up to $8 \mathrm{~mm}$ long. Rhizoids well developed, pale brown, densely distributed along the stem. Stem leaves erect-appressed when dry, spreading when moist, ovate-lanceolate in shape, 2.3-3.3 $\times$ 0.5-0.8 mm, keeled, long acuminate, sharply acute; margins broadly revolute from base to near apex, entire. Upper laminal cells isodiametric to short elongate, (9-)10-12(-13) $\times 8-14 \mu \mathrm{m}$, fairly thick-walled, with tall 2-3 mostly branched papillae $(3-6 \mu \mathrm{m})$; basal laminal cells elongate rectangular to rhomboidal, thick-walled, 40-95 $\times 10-16 \mu \mathrm{m}$, smooth. Alar cells slightly differentiated, forming small auricules with a row of almost quadrate cells along margin. Costa ending near apex. Sexual condition goniautoicous. Seta $0.8-1.5 \mathrm{~mm}$, ochrea up to $1 / 3$ of the seta, vaginula haired. Capsule immersed to emergent; urn-shaped ovoid to oblong-ovoid, about $2.5 \mathrm{~mm}$ long, yellowish brown or pale brown with 8 short furrows, not constricted below the mouth when dry. Exothecial cells not or only differentiated in upper part of capsule. Stomata superficial, situated in the lower part of the capsule. Peristome double. Endostome formed by 8 segments, whitish, erect when dry, smooth on both internal and external side; biseriate (at least at base). 
Exostome teeth 16, yellow to light brown, reflexed when dry. Ornamentation of the external side (OPL): roughly papillose; of the internal side (PPL) slightly ornamented with papillae. Calyptra conic-oblong, light brown, in the upper part hairy with long hairs. Lid with long beak. Spores 20-25 $\mu \mathrm{m}$, densely papillose. Asexual reproduction not observed.

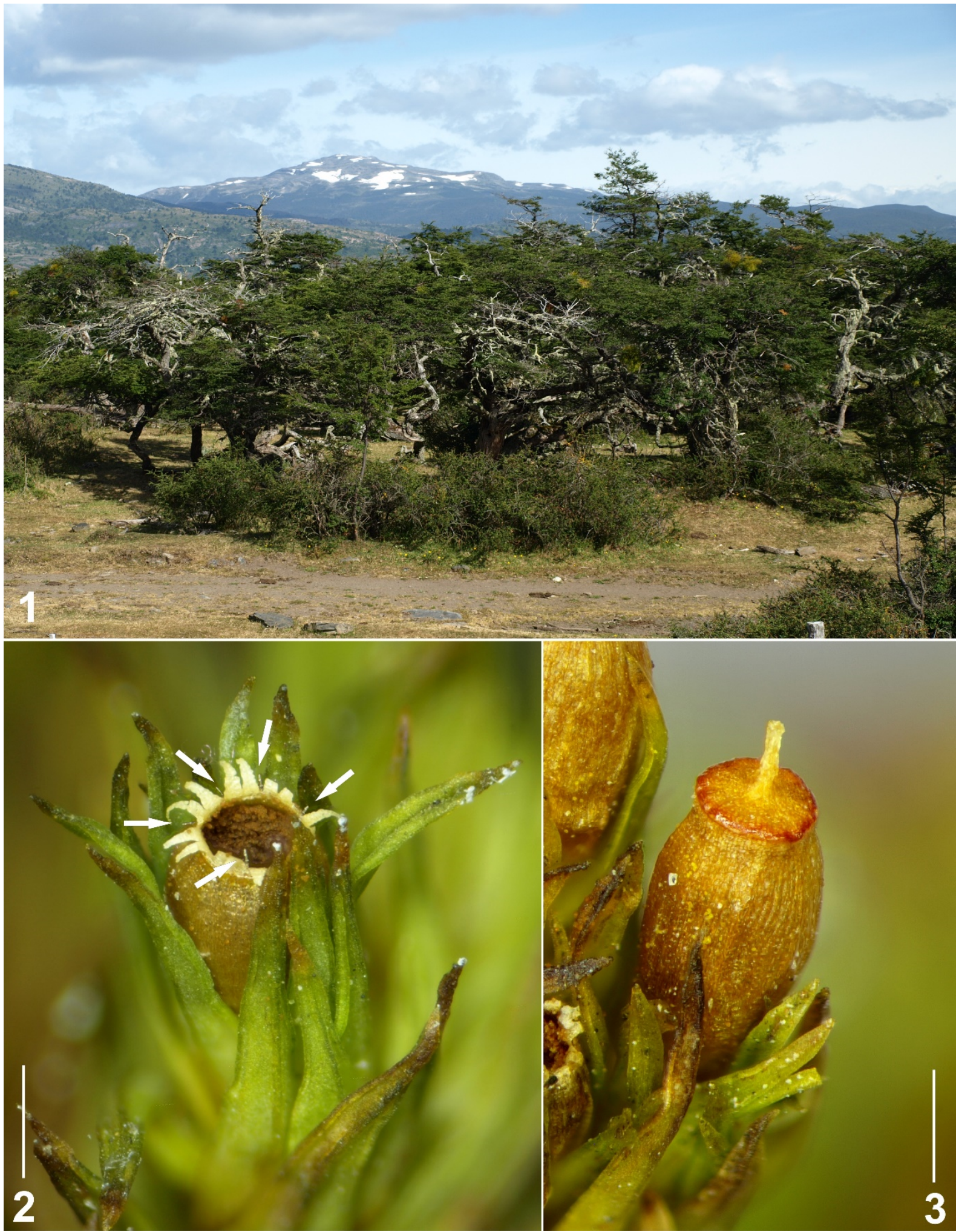

Fig 1-3: Lewinskya anaglyptodon var. ochyrarum. 1. Locality where the taxon was collected: vicinity of Puerto Natales town (Chile, Patagonia), sparse forest of Nothofagus antarctica. 2. Capsule with double peristome; white arrows show endostome segments. 3. Operculate capsule; lid with long beak. Scale bars: $1 \mathrm{~mm}$ (2-3). Photos of the holotype specimen were taken by V. Plášek. 

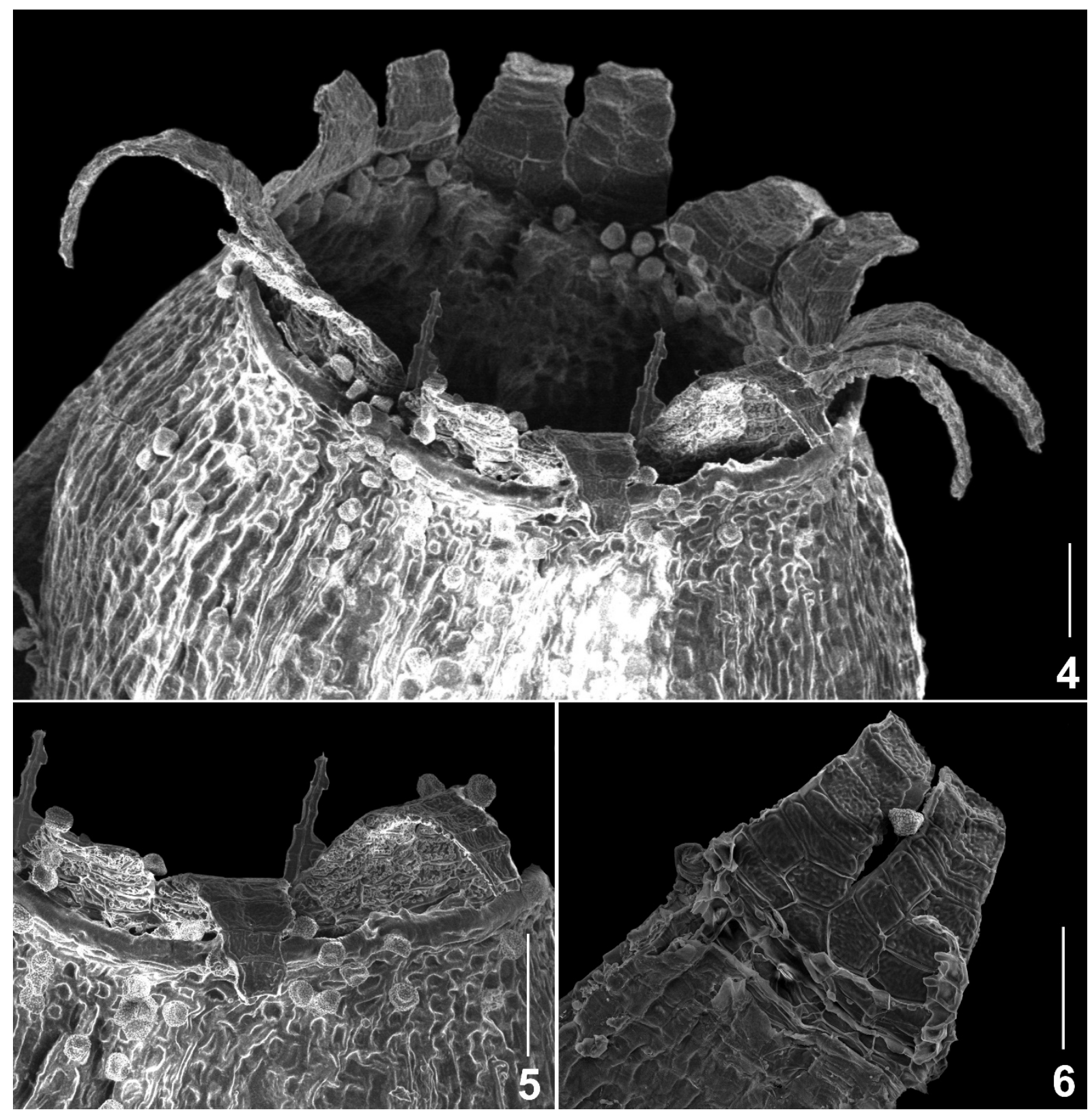

Fig 4-6: SEM micrographs of Lewinskya anaglyptodon var. ochyrarum. 4. View of double peristome 5. External view of peristome showing OPL/PPL ornamentation of the exostome and PPL ornamentation of the endostome 6. IPL ornamentation of endostome segment and exostome teeth. Scale bars: $100 \mu \mathrm{m}$ (4-6). Photos of the holotype specimen were taken by V. Plášek.

\section{Ecology}

The new variety was firstly observed growing on the bark of Nothofagus antarctica (G. Forst.) Oerst., in the middle part of the trunk, on the northern side, at a height of $165 \mathrm{~cm}$ above ground. The population size was about $8 \mathrm{~cm}^{2}$, and it was accompanied by Macrocoma sullivantii (Müll. Hal.) Grout, Orthotrichum assimile Müll. Hal., and Lewinskya elegantula (Schimp. ex Mitt.) F.Lara, Garilleti \& Goffinet. The phorophyte was a part of a sparse forest community of Nothofagus trees, growing along a gravel road.

\section{Etymology}

I am pleased to name the variety after my colleagues and friends Ryszard Ochyra and Halina BednarekOchyra, in honor of their taxonomy works. 


\section{Discussion}

Lewinskya anaglyptodon var. ochyrarum is similar to the type variety of L. anaglyptodon in terms of many gametophytic and sporophytic characters, but it can be easily distinguished by having double peristome with conspicuous 8 endostome segments which were not described in nominal variety (Lewinsky 1987).

Lewinskya rupestris (Schwägr.) F.Lara, Garilleti \& Goffinet, which seems superficially related to L. anaglyptodon var. ochyracea, can be differentiated from them latter mainly due to the spreading (not reflexed) exostome teeth.

\section{References}

Lara F., Garilleti R., Goffinet B., Draper I., Medina R., Vigalondo B. \& Mazimpaka, V. (2016): Lewinskya, a new genus to accommodate the phaneroporous and monoicous taxa of Orthotrichum (Bryophyta, Orthotrichaceae). - Cryptogamie Bryologie 37: 361-382.

Lewinsky J. (1987): Orthotrichum Hedw. (Orthotrichaceae) in South America 2. Taxonomic revision of taxa with superficial stomata. - Memoirs of the New York Botanical Garden 45: 326-370.

Müller F. (2009) An updated checklist of the mosses of Chile. - Archive for Bryology 58: 1-124.

Author's address: Vítězslav Plášek, Dept. of Biology and Ecology, University of Ostrava, Chittussiho 10, CZ-710 00 Ostrava, Czech Republic.

E-mail: vitezslav.plasek@osu.cz 